\title{
Impact of socio-demographic factors on job satisfaction among academic staff of universities in Ghana
}

Milledzi, Eugene Yaw

University of Cape Coast, Cape Coast, Ghana (milledzieugune@yahoo.com; emilledzi@ucc.edu.gh)

Amponsah, Mark Owusu $\bowtie$

University of Cape Coast, Cape Coast, Ghana (mamponsah@ucc.edu.gh; mclaureen2014@gmail.com)

Asamani, Lebbaeus

University of Cape Coast, Cape Coast, Ghana (lebbaeusa@gmail.com)



ISSN: $2243-7703$ Online ISSN: 2243-7711

OPEN ACCESS

\section{Abstract}

The study examined the effect of age, rank, marital status and gender on job satisfaction among academic staff of universities in Ghana. The descriptive survey design was employed for the study. A proportional stratified random sample of 361 academic staff made up of 287 males and 74 females completed a validated survey questionnaire. The results of ANOVA show a significant positive effect of age, rank and marital status on job satisfaction among academic staff of universities in Ghana with senior lecturers being the most satisfied academic staff among the ranks. Independent samples t-test results found no significant difference between male and female members of the academic staff with regard to their levels of job satisfaction. It is recommended from the study that universities in Ghana engage young academics who have the opportunity of progressing on the academic ladder.

Keywords: universities; academic staff; job satisfaction; rank; gender differences; marital status and age 


\section{Impact of socio-demographic factors on job satisfaction among academic staff of universities in Ghana}

\section{Introduction}

Job satisfaction has been defined in various ways by different authors and researchers. Shah (2012) defined job satisfaction as any combination of psychological and environmental circumstances that cause a person to be satisfied with his or her job. Psychological circumstances include factors such as achievement and work accomplishment where the individuals receive good assessment or evaluation from superiors and other colleagues at the work place. Environmental circumstances include factors such as safety and security issues in the work environment, satisfaction with regard to resources like office space, internet facilities and computers. Office space provided to university academics ought to be conducive and the work environment must provide opportunities for academics to concentrate and focus on their tasks without distraction.

According to Schneider (2008), job satisfaction is the totality of an individual's social and psychological wellbeing at the work place. Socially, it implies that the individual is satisfied with the relationship with his or her co-workers where there is team spirit, social support, collaboration to achieve results as well as fairness in the application of rules and regulations to all. Psychological wellbeing means the worker is satisfied with the emotional support system at the work environment with regard to feeling a sense of belonging, being involved in decision making as well as satisfaction with opportunities for professional growth and development for self-actualization.

Armstrong (2006) opined that, job satisfaction is the fulfilment acquired with experiencing various job activities and reward by employees. Fulfilment implies that the worker derives satisfaction in doing the work as well as feeling a sense of pride in accomplishing a given assignment or task. Satisfaction with reward is where employees feel that there is equity in compensation and that salaries and allowances they receive commensurate with the work they do. According to Daft and Noe (2001), job satisfaction is a psychological response which is reflected in the evaluations that employees make of all the salient aspects of their job and the organisation for which they work. The salient aspects of the job include the nature of work, safety at the work place, opportunities for advancement or promotion and adequate compensation or reward systems that have been put in place by the management of the organisation. The foregoing definition is restricted to only the psychological perspectives of job satisfaction and did not touch on the social dimensions such as satisfaction with regard to relationships with co-workers and the social support system at the work place.

Sohail and Delin (2013) have asserted that job satisfaction is the good feelings that an employee has about his or her work as well as the organisational environment. This definition linked job satisfaction to employees perceiving their organisational environment in positive terms. The focus is on organisational policies, structures, systems and procedures within the organisation that boost satisfaction of employees. Hence in academic institutions such as universities, these policies and procedures need to convey a message on the nature of the institution, their core mandates and values to academic staff in order to give them a sense of direction as well as improving teamwork and synergy at the work place.

In their explanation of job satisfaction, Nel, Van-Dyk, Haasdroek, Schultz, Sano, and Werner (2004), synthesises that, job satisfaction is the positive perception of workers about the nature of rewards that are appropriate and meaningful and are commensurable to the amount of efforts that led to the rewards. These rewards can be intrinsic such as achievement and recognition or extrinsic such as salary and fringe benefits. However, McCarry (2005) looks at job satisfaction from the perspective of monetary rewards that are equitably distributed among employees. This assertion of monetary rewards at the work place has ignored other important aspects of job satisfaction that are non-monetary such as accomplishment, recognition as well as pep talks which 
are also highly effective means of boosting job satisfaction levels since job satisfaction is a bi-dimensional concept consisting of intrinsic and extrinsic satisfaction dimensions. The intrinsic dimensions of job satisfaction largely depend on individual characteristics of an employee such as ability to use initiative, accepting responsibility and the work that the person actually performs. Extrinsic dimensions of job satisfaction, on the other hand, are situational and depend on the environment such as organisational policy which implies the mandate and direction of the organisation, safety and security measures put in place in the organisation as well as financial and other material rewards.

\subsection{Age and job satisfaction}

Robins (2001) has contended that job satisfaction declines with increasing age while Saleh and Otis (1964) have indicated that job satisfaction increases with age. According to Saleh and Otis (1964), increase in job satisfaction with age may be due to social and remunerative advantages of staying and advancing on the job. This implies that age and experience are social and economic factors that relate to intrinsic factors that facilitate workers' satisfaction on the job. Therefore, the more advanced in age and experience a workers are, the more satisfied they are; and the less likely they express the desire to leave the organization.

Cano and Miller (1992) in a study of agricultural education teachers in Ohio found that age, number of years in current position and degree status are not significantly related to their overall levels of job satisfaction. In contrast, Nester and Leary (2000) in a study found a significant effect of age on levels of job satisfaction among agricultural extension agents. The study shows that job satisfaction is higher for those in the age groups of 23-33 and 46-50. Similarly, the findings of Bowen, Radhakrishna, and Keyser, (1994) indicated that age is significantly related to job satisfaction since in their study it was found that those who were older have higher levels of job satisfaction. Andrews (1990) on the other hand, in a study established no significant effect of age on levels of job satisfaction among extension agricultural agents.

A critical look at the literature shows that in some studies, age as a socio-demographic variable is significantly related to overall levels of job satisfaction while in other studies age is not significantly related to job satisfaction. The findings of Ohio researchers on the relationship between age and levels of job satisfaction are contrary to the findings of Grady (1985). For example, Grady (198) in a study found that as the age of the teacher increased, so did his or her overall job satisfaction level decrease.

Other researchers in the field have also attempted to establish relationships between age and levels of job satisfaction. The results of these studies have been contradictory. This is because five different types of relationships namely: positive linear, negative linear-shaped, inverted U-shaped and no significant relationship have been reported. For example, the relationship between age and job satisfaction tends to be a U-shaped function where job satisfaction with younger employees is initially high and then drops for several years, and finally increases again with employees age (Waskiewicz, 1999). However, Green (2000) in a study found that age was not related to job satisfaction.

Rhodes (1983), in a comprehensive literature review, found that the relationship between age and job satisfaction is best represented by a positive linear relationship. Even though this relationship was revealed in most studies, the strength of the relationship was weak, with correlations falling between 0.10 and 0.20 . Brush, Moch, and Pooyan (1987) conducted a meta-analysis in an attempt to estimate the population parameter representing the relationship between age and levels of job satisfaction. The results showed a mean correlation coefficient of 0.22 for the association between age and job satisfaction. However, further analysis revealed that the type of organisation (manufacturing, service, government) moderated the relationship. Individual parameters varied between types of organisation which suggests that the age-job satisfaction relationship is not stable across organisation types. Green (2000) conducted a subsequent meta-analysis to assess the relationship between age and job satisfaction that included a larger number of sample than the previous meta-analytic investigations. Their results showed that the relationship between age and job satisfaction was positive but weak in magnitude ( $\mathrm{r}$ 
Milledzi, E. Y., Amponsah, M. O., \& Asamani, L.

$=.07$ ). In addition, type of occupation moderated the relationship between age and levels of job satisfaction.

Taking a critical look at the outcomes of these two meta-analyses studies, one can point out some similarities and differences. First, the results are similar in finding some type of organisational grouping (by organisation or occupation type) moderating the age and job satisfaction relationship. Though the categories used as moderators differ by name, both reveal some organisational element influencing the association. Conversely, the results of the two studies contradict each other by finding differing strengths of the relationship. While Brush et at., (1987) found a moderate relationship $(\mathrm{r}=0.22)$, Sterns (1995) results showed a much weaker association $(\mathrm{r}=0.07)$.

Although the foregoing meta-analyses provided important information about the strength of age and job satisfaction relationship, they are not capable of distinguishing the actual shape of it. This is because meta-analysis utilizes linear correlation coefficients from past studies as data points. Therefore, an analyst is unable to identify any nonlinear relationships. In other words, nonlinear relations could be evident within the data sets, but the meta-analysis only explains the proportion of the variance that is linear. Consequently, meta-analytic results may not truly represent the strength of the relationship if nonlinear relations are evident. We can therefore point out that both meta-analytic studies that have been reviewed may not have substantially advanced our knowledge about the strength of the relationship between age and job satisfaction as its shape has been left undetermined.

In order to fill this gap, some researchers have attempted to determine the form of the relationship between age and job satisfaction (Clark, Oswald, \& Warr, 1996; Kacmar \& Ferris, 1989; Warr, 1992). Though these research efforts have the potential to provide vital information concerning both the shape and strength of the relationship, each study has various methodological problems that inherently limit the validity of their conclusions. For example, Kacmar and Ferris (1989) found significant nonlinear variance evident for extrinsic satisfaction, but not for intrinsic satisfaction. The results of this study may be questioned because of two factors. First, a small sample size $(N=81)$ was used, which increases random sampling error. Second, the participants used were employed in a single occupation within one organisation (i.e., nurses from one hospital). Their results therefore may have been influenced by type of occupation and type of organisation specific variables. In any case, both factors may have ultimately contributed to biases in their conclusions.

Clark et al. (1996) have attempted to determine the shape of the age-job satisfaction relationship using a large sample $(N=5,192)$ of British employees. The results of the study indicated that the relationship between age and job satisfaction is $\mathrm{U}$-shaped. Although this study used a sample that was characteristic of the working population, a potential problem remains with its measurement of the different facets of job satisfaction. Each job satisfaction facet considered in the study was measured via single-item measures. It is important to note that single-item measures have a tendency to be unreliable, which raises questions concerning how well the facets of job satisfaction were actually measured. Moreover, the construct validity of the facets of job satisfaction could also be questioned as scale unreliability can also affect what specific construct is being measured.

From the review we notice that researchers and scholars have investigated the relationships that exist between age and job satisfaction but two questions remain unanswered. First, given that there is a positive relationship between age and job satisfaction, is it simply linear or does it contain a nonlinear component? Second, what underlying variables can account for the pattern of job satisfaction differences between age groups? The current study is therefore an attempt to fill this research gap.

\subsection{Rank and job satisfaction}

The term rank as used in job satisfaction studies refers to an individual's status in an organisation and indicates an employee's job level or job seniority in a particular occupational classification (Oshagbemi, 2003). Rank is a person's status or position in a group, which often is determined by a person's characteristics. Within the context of universities in Ghana, rank indicates whether an academician is an assistant lecturer, lecturer, 
senior lecturer, associate professor, or professor. Moreover, majority of job satisfaction studies for a long time have focused on industrial and organisational settings. Therefore, empirical evidence regarding job satisfaction of higher education teachers particularly among university academics is scarce in the international literature (Oshagbemi, 2003; Tack \& Patitu, 1992). According to Pearson and Seiler (1983), this area has not received much attention because a high level of job satisfaction has generally been presumed to exist in a university setting.

A survey of the literature reveals that studies designed to investigate whether job satisfaction increases with rank have shown inconsistent results. Oshagbemi (2003) in a study concluded that rank is a reliable predictor of job satisfaction with workers of higher ranks generally being satisfied with their jobs as compared to those of lower ranks. Higher rank employees indicate higher levels of job satisfaction because higher-level jobs tend to be more complex and have better working conditions such as pay and promotion prospects, supervision and responsibility. However, in a study conducted in Northern Cyprus, the level of job satisfaction of academics did not increase with rank (Eyupoglu \& Saner, 2009). Similarly, Platsidou and Diamantopoulou (2009) in a study on job satisfaction of Greek university academics found that academic rank had no significant effect on faculty job satisfaction.

Conversely, in their study that examined the relationship between rank, age, and gender and overall job satisfaction, Near, Rice, and Hunt, (1978) found that the strongest predictor of job satisfaction was rank. Holden and Black (1996) indicated clear differences in the levels of job satisfaction and productivity among psychologists employed as faculty members in a medical school with full professors displaying higher levels of job satisfaction and productivity when compared with associate professors and assistant professors.

Oshagbemi (1997) examined the effects of rank on job satisfaction of UK academics found that overall job satisfaction increased progressively with rank. Ssenga and Gerrett (2005) in their study of the job satisfaction of university teachers in Uganda concluded that rank significantly predicted academic staff job satisfaction. Similarly, Noble and McCornic (2008) found rank to be a significant predictor of job satisfaction in their study of job satisfaction among primary school staff.

\subsection{Marital status and job satisfaction}

No clear consensus has been reached with regard to the effect of marital status on job satisfaction of university academics and the effect appears to vary by gender. Some studies have shown that men who are married have higher publication rates and job satisfaction than single men Sax et al. (2002). On the other hand, Campbel, Converse, and Rodger (1976) found that single men are more satisfied with their jobs than married men, but no difference was evident for females. Other studies have concluded that marriage increased job satisfaction for faculty members at all levels (Cetin, 2006; Hagedorn, 2000).

Result of a study conducted by Olatunji (2014) found a significant difference in job satisfaction between married and single employees with those who are married reporting higher job satisfaction than those who are single. Marriage has been found to have positive effect on job satisfaction of male faculty members and in some cases it has no effect on career attainment and job satisfaction (Sonert \& Holden, 1995). Berssoff and Crosby (1984) in a study found that the effect of marital status has more impact on male faculty job satisfaction than female faculty job satisfaction.

Wolfinger, Mason, and Goulden (2008) investigated the differences between marital status and job satisfaction among employees. They found a significant difference between marital status and job satisfaction among employees with workers who are divorced and widowed being more satisfied with their job than their married counterparts. They argued that the two critical areas of life are job and family. As a result, balancing out the needs of these two domains is of a great importance. If an individual encounters a problem in one of those areas, he or she would be challenged in the other one as well. Stress and difficult working conditions in some jobs have significant negative effects on physical and mental efficiency of the employee and it would also distort 
Milledzi, E. Y., Amponsah, M. O., \& Asamani, L.

his/her family and social relationships greatly.

Weaver (1974) investigated the relationship between marital status and job satisfaction and concluded that the two variables are positively correlated. In their investigation of the relationship between marital status and job satisfaction in long term and gender differences, Rogers and May (2003) observed that job satisfaction and marital status were significantly correlated in long term. An increase in marital satisfaction was significantly related to an increase in job satisfaction. Furthermore, there was a negative correlation between marital disorders and job satisfaction, and this was similarly observed in both women and men.

With regard to the effect of marital status on job satisfaction, the literature shows contradictory research findings. Some studies have established that married people report higher levels of job satisfaction than people who are not married (Bersoff \& Crosby; Martin \& Hanson, 1985). Sohail and Delin (2013) indicated that marital status affects job satisfaction differently for men and women. Men who are married reported less job satisfaction than men who are not married. The reverse is true for mothers who reported higher job satisfaction than women who are not mothers. Warren and Johnson (1995) in a study established that working women with children reported lower job satisfaction than working men with children. Research has shown that many married women experienced work-family conflict leading to job dissatisfaction (Greenhaus, Parasuraman, \& Collins, 2001). A close look at the literature shows that even though studies have been done in this area, the effect of marital status on job satisfaction still remains unclear.

\subsection{Gender and job satisfaction}

Gender has been noted as an explanatory variable in many studies. Studies have shown that job satisfaction can be influenced by a variety of socio-demographic variables such as gender. A number of studies involving gender and levels of job satisfaction have been done. However, the literature is divergent indicating that in some studies females have higher levels of job satisfaction while other studies indicate that males have higher levels of job satisfaction (Bowen et al., 1994). There are even some studies that found no significant difference between male and female with regard to their levels of job satisfaction. For example, Azim, Haque, and Chowdhurry (2013) in a study found no significant difference in job satisfaction between male and female. Whereas Nester and Leary (2000) in a study found no significant difference in levels of job satisfaction between male and female; Riggs and Beus (1994) on the other hand, indicated that as the number of areas of responsibility increased for females, job satisfaction increased as well. The opposite is true for males indicating that as their areas of responsibility increased, their job satisfaction levels decreased.

Riggs and Beus (1994) in a study of gender differences in job satisfaction of agricultural extension agents found that female extension agents were more satisfied with their jobs than their male counterparts. In contrast, Olatunji (2014) contends that males reported higher levels of job satisfaction than females in their study of health workers. Clark (1997) underscores that female workers tend to report higher levels of job satisfaction than males while Ward and Sloane (2000) in a study found that for Scottish workers, males have higher levels of job satisfaction than females. Booth, Francesconi, and Frank (2002) indicate that females are even less satisfied with their levels of promotion prospects than males, but then they are more satisfied with their salaries than their male counterparts. In a study, Castillo, Conklin, and Cano (2008) found no significant gender differences in levels of job satisfaction. They reported that both males and females were satisfied with their jobs.

One specific area of investigation is the study of differing levels of reported job satisfaction by gender. Practically all studies (Clark, 1997; Sloane \& Williams, 2000; Sousa-Poza \& Sousa-Poza, 2003; Long, 2005) have shown that females possess higher levels of job satisfaction compared to males, a puzzling outcome when one considers the existence of gender wage differentials in favor of males, as well as occupational segregation by gender, with women occupying jobs with lower prestige. Clark (1997) in a study found gender differences in levels of job satisfaction in Britain and indicated that females have greater levels of satisfaction compared to males, despite being in jobs with lower earnings and promotion opportunities compared to males. 
Impact of socio-demographic factors on job satisfaction among academic staff of universities in Ghana

Results from a study conducted by Kessuwan and Muenjohn (2010) revealed that there were no significant differences between males and females with regard to their levels of job satisfaction. In contrast, some studies found that men were more satisfied than their female counterparts (Hulin \& Smith, 1964; Weaver, 1974; Forgionne \& Peeters, 1982). The possible reason for different levels of job satisfaction reported for male and female employees may be due to their different types of expectations from the job. For example, to male employees, career is of central importance, which is not for their female counterparts.

Sloane and Williams (2000) reported higher levels of job satisfaction for females compared to males, despite earning lower pay. They indicated that this could be due to females having lower expectations. Nevertheless, females in male dominated workplaces have similar satisfaction levels compared to males, perhaps reflecting higher expectations. Souza-Poza and Sousa-Poza (2003) undertook a meta-analysis in Britain using 1991-2000 data and found evidence of falling levels of job satisfaction among females over time. Similar to Clark's (1997) as well as Sloane and William's (2000) findings, Donohue and Heywood (2004) found no gender job satisfaction gap for young United States workers, once again indicating that specific female labor market groups possess expectation levels similar to those of their male counterparts.

Long (2005) used cross-sectional data to investigate gender differences in job satisfaction. The results showed that females were more satisfied with their job compared to males. This is consistent with the findings of McNeely (1984) who reported a significant gender difference in levels of job satisfaction with females being more satisfied than males. These findings were supported by Tuch and Martin (1991) in which female employees were more satisfied than their male counterparts. However, a study by Barber (1986) found no significant job satisfaction differences between male and female human service workers. Similarly, Jayaratne and Chess (1984) in a study found no significant differences between male and female with regard to promotion, financial rewards, work environment and role conflict. These findings were supported by Rentner and Bissland (1990) who in a study found no significant differences between male and female public relation workers with regard to their overall job satisfaction. It is important to note that most of the studies have found no significant differences in the level of job satisfaction between male and female employees, particularly when a number of other variables were statistically controlled. It is therefore worth investigating if these controversies that exist between gender and job satisfaction are true.

The literature so far shows inconsistencies in the findings. Considering gender, there are no conclusions about the differences between males and females levels of job satisfaction. Some empirical studies reviewed by Herzberg (1959) indicate that males are more satisfied with their jobs while others contend that females are more satisfied. Looking at the literature, it suggests that a clear conclusion cannot be drawn with regard to gender and levels of job satisfaction. Therefore further research is needed to establish if any differences exist with regard to gender and levels of job satisfaction.

\subsection{Statement of the problem}

Since the Hawthorne studies were done in the 1920s by Elton Mayo at the Western Electronic Company, there have been several studies on the nature, causes and correlates of job satisfaction. However, it has been observed that these studies left education and did not address issue in higher education particularly the impact of socio-demographic factors on job satisfaction of academic staff of universities. Studies that investigated job satisfaction focused on organizational and industrial settings and relied on quantitative data from respondents (Lacy \& Sheehann, 1997). Other researchers touched on only psychological variables (intrinsic and extrinsic factors) and left out socio-demographic factors such as age, rank marital status and gender. It must be noted that the way a male academic staff assesses job satisfaction may differ from that of a female academic staff. Also, different age groups may pose varying perceived views about job satisfaction levels so are marital status and rank.

Also, the vast majority of earlier studies conducted in job satisfaction have been done in advanced and 
Milledzi, E. Y., Amponsah, M. O., \& Asamani, L.

industrial nations such as North America, United Kingdom and other parts of Western Europe (Mullins, 2002). Evidence from developing nations is unfortunately lacking. It is also not clear to what extent the theoretical models of job satisfaction developed in these advanced and industrialized nations apply to other national contexts, particularly in developing countries. While literature abounds on job satisfaction of workers in industrial and organizational settings, the same cannot be said about socio-demographic factors from the perspective of higher education especially with regard to academic staff of universities in a developing nation like Ghana. This study therefore sought to examine job satisfaction within the educational context by exploring the impact of socio-demographic factors such as age, rank, marital status and gender on job satisfaction among university academic staff in Ghana. The present study is an attempt to fill a research gap in the area of job satisfaction in higher education.

\subsection{Purpose of the Study}

The purpose of the study was to examine the effect of socio-demographic factors on job satisfaction among academic staff of universities in Ghana. Specifically the study assessed the effect of age, rank, marital status and gender on job satisfaction of academic staff.

\subsection{Hypotheses}

The following null hypotheses were formulated to guide the study.

$>$ Age does not have a statistically significant impact on job satisfaction among academic staff of public and private universities in Ghana.

> Rank does not have a statistically significant impact on job satisfaction among academic staff of public and private universities in Ghana.

Darital status does not have a statistically significant impact on job satisfaction among academic staff of public and private universities in Ghana.

$>$ There is no statistically significant difference in the job satisfaction of male and female academic staff of public and private universities in Ghana.

\subsection{Significance of the study}

The study will serve as a manual to universities and their staff in the sense that, it will unearth the positive characteristics that their staff can use to enable them improves on their job in the academic environment. Besides, it will serve as a guide for university teachers in the delivery of the curriculum as they work with the administrators. Again the findings could help university academic staff pursue excellence at the workplace if policy makers took into consideration issues about their job satisfaction. Other stakeholders including personnel of the Ministry of Education (MOE) could consult this piece in addition to what is available to them.

\section{Methodology}

\subsection{Research Design}

The descriptive survey was used for the study. According to Creswell (2014), descriptive surveys gather data at a particular point in time when there is an intention of describing the nature of existing conditions or identifying standards against which existing conditions can be compared. Surveys are also capable of providing descriptive, inferential and explanatory information that can be used to ascertain correlations and relationships between items and the themes of the survey (Cohen, Manion, \& Morrison, 2007). For Polit and Beck (2008), descriptive surveys gather information to represent what is going on at only one point in time. This study in the 
first place sought to explore the effect of socio-demographic factors on job satisfaction among academic staff of universities in Ghana. To be able to accomplish this, there is the need to gather data from a wide population of academic staff in order to make generalizations. Also, there is the need to provide descriptive and inferential information on academic staff perception of their psychosocial work environment. This therefore calls for the gathering of standardized information by using the same instruments and questions for all sampled respondents. To meet these expectations, the study employed the descriptive survey of academic staff socio-demographic characteristics and psychosocial work environment of job satisfaction.

Considering the nature of the research problem, the researchers selected conditions that already existed for analysis of their relationships. It must be pointed out that surveys also have their pitfalls among which is the inability to ask probing questions as well as inability to seek clarifications especially when structured or closed ended questionnaires are used as data collection instrument. Despite the deficiencies, the descriptive survey design was chosen for this study because judging from the main thrust of the study where data was collect at just one point in time on samples from academic staff of universities in Ghana; it was deemed the most appropriate design.

\subsection{Population and Sample}

The target population for the study involved all academic staff of public and private universities in Ghana as of March, 2014 spread over all faculties, schools and colleges. The accessible population for this study was however, all academic staff of University of Ghana, Kwame Nkrumah University of Science and Technology, Valley View University and Catholic University College. This consists of assistant lecturers, lecturers, senior lecturers, associate professors, and professors. As at 2014, the total population of academic staff in the four universities under study was 1737 . The distribution of the population of academic staff by institution, rank and gender is shown in Table 1.

\section{Table 1}

Distribution of Population among the Universities

\begin{tabular}{|c|c|c|c|c|c|c|c|c|c|c|}
\hline \multirow{3}{*}{ Rank of university academic staff } & \multicolumn{4}{|c|}{ Public } & \multicolumn{4}{|c|}{ Private } & \multirow{2}{*}{\multicolumn{2}{|c|}{ Total }} \\
\hline & \multicolumn{2}{|c|}{$\mathrm{UG}$} & \multicolumn{2}{|c|}{ KNUST } & \multicolumn{2}{|c|}{ CUC } & \multicolumn{2}{|c|}{ VVU } & & \\
\hline & M & $\mathrm{F}$ & M & $\mathrm{F}$ & $\mathrm{M}$ & $\mathrm{F}$ & $\mathrm{M}$ & $\mathrm{F}$ & M & $\mathrm{F}$ \\
\hline Professor & 55 & 5 & 13 & 0 & 1 & 0 & 1 & 0 & 70 & 5 \\
\hline Ass Professor & 79 & 33 & 44 & 4 & 0 & 0 & 1 & 0 & 124 & 37 \\
\hline Senior Lecturer & 178 & 45 & 133 & 17 & 4 & 2 & 4 & 0 & 319 & 64 \\
\hline Lecturer & 281 & 88 & 389 & 71 & 46 & 8 & 39 & 7 & 755 & 174 \\
\hline Asst. Lecturer & 102 & 65 & 0 & 0 & 0 & 0 & 15 & 7 & 117 & 72 \\
\hline Total & 695 & 236 & 579 & 92 & 51 & 10 & 60 & 14 & 1385 & 352 \\
\hline
\end{tabular}

Source. UG, 2014; VVU, 2014; CUC, 2014; KNUST, 2014.

\subsection{Sampling Techniques}

To be able to select a representative sample of the population, this study was guided by Kirk (1995) recommendation that it is appropriate to select a sample size of 20 percent or more for a population of 1737. Therefore, a sample size of 376 was established which is 20 percent of the population of the four universities selected for the study. For example, a proportion of 20 percent was calculated among the four universities which included 194, 142, 22, 18 academic staff from University of Ghana, Kwame Nkrumah University of Science and Technology, Valley View University and Catholic University College respectively. The probability sampling specifically, the proportional stratified random sampling technique was employed. In stratified random sampling, the population is divided in to a number of strata and a sample is drawn from each stratum (Fowler, 2009). The division of the population into strata is based on one or more significant criteria such as rank, gender, age, or socio-economic status (Creswell, 2014). The rationale for employing stratified sampling in this study was that it provides the opportunities for generalisation of research findings to the population. In this study, stratification 
Milledzi, E. Y., Amponsah, M. O., \& Asamani, L.

was done based on rank and gender of university academic staff. The researchers collected the list of the academic staff from the Divisions of Human Resource of University of Ghana, University of Science and Technology, Valley View University and Catholic University College. From the list, a proportional stratified sampling technique was employed to select 376 academic staff made up of 294 males and 82 females for the study.

\subsection{Data Collection Instrument}

Taking ideas from Spector's (1985) Job Satisfaction Survey Questionnaire, a questionnaire of the Likert type scale of Academic Staff Job Satisfaction was developed by the researchers based on the variables considered as well as the objectives of the study. The questionnaire was divided into two sections. The first section dealt with the socio-demographic characteristics of the respondents. It sought to gather information on gender, age, rank, marital status and category of university (public and private). The second section was measured on a five point scale such as one (1) indicating the least agreement to the issues while five (5) representing the strongest agreement to the issues. Examples of items that measured the job satisfaction of academic staff included:

> 1 - I am satisfied with the various forms of rewards given to me in this university.

$>\quad 2$ - I am satisfied with the various forms of promotion criteria used in this university.

> 3 - I am satisfied with the core mandate and direction of this university.

> 4 - I am satisfied with the freedom for initiative and creativity in the execution of my responsibilities in this university.

The reliability co-efficient of the questionnaire was established using the Cronbach's alpha since the responses to the items on the questionnaire were measured discretely or numerically. A reliability co-efficient of 0.91 was obtained which was deemed to be appropriate (Field, 2005). According to Pallant (2001), any reliability co-efficient that is equal to 0.7 or more is presumed to be statistically significant. The reliability test, therefore, indicates the ability of the instrument to generate consistent result.

\subsection{Data Collection Procedure}

Prior to administration of the questionnaire, the consents of academic staff selected to participate in the study were sought and contacted. The purpose of the study was explained to them and the questionnaires were given out to the 376 selected academic staff to complete. At the end of the data collection, 361 completed questionnaires were retrieved representing 96.0 percent response rate.

\subsection{Data Analysis}

The data obtained were analysed using inferential statistics. For hypotheses 1, 2, and 3, the two-way between group analysis of variance (ANOVA) was employed while the Independent samples t-test was used to analyse the data on hypothesis 4 . All the hypotheses were tested at the 0.05 alpha level of significance. The data were analysed with the Predictive Analytic Software (PASW) Version 19.0.

\section{Results and discussions}

The main objective of this study was to examine the impact of socio-demographic factors (age, rank, marital status, gender) on job satisfaction of academic staff of universities in Ghana. To examine the impact of age on job satisfaction among academic staff of public and private universities in Ghana, the two-way between group analysis of variance (ANOVA) was conducted. The respondents' age groups were in eight categories (Group 1: Less than 30 years; Group 2: $30-34$ years; Group 3: $35-39$ years; Group 4: $40-44$ years; Group 5: $45-49$ years; Group 6: $50-54$ years; Group 7: $55-59$ years; Group 8: 60 years and above). The age group and 
category of university (public and private) were treated as the independent variables while the dependent variable was academic staff job satisfaction. Also, a post-hoc test was conducted using Tukey HSD to find out where the actual differences occur. In order to quantify the differences and also, to know the margin of the differences, the eta square values were calculated for the differences if any. Table 2 presents the results of the descriptive statistics.

As shown in Table 2, none of the academic staff in both public and private universities who participated in the study were below 30 years. Table 2 further shows that academic staff of private universities who were within the age groups of $30-34$ years $($ Mean = 3.04, Std. Dev. =0.70), $45-49$ years $($ Mean = 3.42, Std. Dev. =0.59), and 60 years and above $($ Mean $=4.10$, Std. Dev. $=0.09$ ) were more satisfied than those in public universities who were within the same age groups. On the other hand, academic staff in public universities who were within the age groups of $35-39$ years $($ Mean = 3.21, Std. Dev. $=0.57), 40-44$ years $($ Mean = 3.12, Std. Dev. $=0.54)$, $50-54$ years $($ Mean $=3.48$, Std. Dev. $=0.55)$, and $55-59$ years $($ Mean $=3.45$, Std. Dev. $=0.49)$ were more satisfied than their counterparts in the private universities.

\section{Table 2}

Descriptive statistics of age group and category with regard to their level of job satisfaction

\begin{tabular}{|c|c|c|c|c|}
\hline Age group of respondent & Category of university & Mean & SD & $\mathrm{N}$ \\
\hline \multirow[t]{2}{*}{ Less than 30 years } & Public & 3.61 & 0.39 & 11 \\
\hline & Total & 3.61 & 0.39 & 11 \\
\hline \multirow[t]{3}{*}{$30-34$ years } & Public & 2.90 & 0.62 & 61 \\
\hline & Private & 3.04 & 0.70 & 12 \\
\hline & Total & 2.92 & 0.63 & 73 \\
\hline \multirow[t]{3}{*}{35 - 39 years } & Public & 3.21 & 0.57 & 53 \\
\hline & Private & 3.07 & 0.78 & 7 \\
\hline & Total & 3.19 & 0.59 & 60 \\
\hline \multirow[t]{3}{*}{$40-44$ years } & Public & 3.12 & 0.54 & 51 \\
\hline & Private & 2.73 & 0.58 & 5 \\
\hline & Total & 3.09 & 0.55 & 56 \\
\hline \multirow[t]{3}{*}{$45-49$ years } & Public & 3.20 & 0.68 & 55 \\
\hline & Private & 3.42 & 0.59 & 2 \\
\hline & Total & 3.21 & 0.68 & 57 \\
\hline \multirow[t]{3}{*}{50 - 54 years } & Public & 3.48 & 0.55 & 49 \\
\hline & Private & 3.07 & 0.59 & 5 \\
\hline & Total & 3.44 & 0.56 & 54 \\
\hline \multirow[t]{3}{*}{55 - 59 years } & Public & 3.45 & 0.49 & 34 \\
\hline & Private & 3.00 & 0.0 & 1 \\
\hline & Total & 3.44 & 0.49 & 35 \\
\hline \multirow[t]{3}{*}{60 years and above } & Public & 3.45 & 0.40 & 10 \\
\hline & Private & 4.10 & 0.09 & 5 \\
\hline & Total & 3.67 & 0.45 & 15 \\
\hline \multirow[t]{3}{*}{ Total } & Public & 3.22 & 0.61 & 324 \\
\hline & Private & 3.17 & 0.71 & 37 \\
\hline & Total & 3.22 & 0.62 & 361 \\
\hline
\end{tabular}

Source. Field data, $2014(\mathrm{~N}=361)$. Dependent Variable: Job satisfaction.

To find out whether there is a difference between the groups with regard to their levels of job satisfaction, the study presented further the test of between-subject effects as depicted in Table 3. After finding out that there was a difference, the study then presented the post-hoc analysis as shown in Table 4. As Table 3 shows, there was a statistically significant main effect for age $[\mathrm{F}(7,346)=4.01, p=0.00]$; however, the effect size was moderate (partial eta squared $=0.08$ ). Post-hoc comparisons using the Tukey HSD test was performed. The post-hoc analysis for the combined data is presented only when there is a statistically significant difference between the 
Milledzi, E. Y., Amponsah, M. O., \& Asamani, L.

respondents with regard to their job satisfaction and age. The results are presented in Table 4.

Table 3

Two-Way ANOVA Test for Age Group, University Category and Academic Staff Level of Job Satisfaction

\begin{tabular}{lcccccc}
\hline \multicolumn{1}{c}{ Source } & $\begin{array}{c}\text { Type III Sum } \\
\text { of Squares }\end{array}$ & df & $\begin{array}{c}\text { Mean } \\
\text { Square }\end{array}$ & F & Sig. & $\begin{array}{c}\text { Partial } \\
\text { Eta } \\
\text { Squared }\end{array}$ \\
\hline Corrected Model & $19.80^{\mathrm{a}}$ & 14 & 1.41 & 4.17 & 0.00 & 0.14 \\
Intercept & 809.44 & 1 & 809.44 & 2.39 & 0.00 & 0.87 \\
Age group & 9.52 & 7 & 1.36 & 4.01 & 0.00 & 0.08 \\
University category & 0.06 & 1 & 0.06 & 0.17 & 0.68 & 0.00 \\
Age group * & & & & & & \\
University category & 3.45 & 6 & 0.56 & 1.69 & 0.12 & 0.03 \\
Error & 117.28 & 346 & 0.34 & & & \\
Total & 3875.22 & 361 & & & & \\
Corrected Total & 137.08 & 360 & & & & \\
R Squared = .144 (Adjusted R Squared = .110) & & & & & \\
\hline
\end{tabular}

Source. Field data, $2014(\mathrm{~N}=361)$. Dependent Variable: Job satisfaction.

\section{Table 4}

Age Differences in Job Satisfaction among Academic Staff

\begin{tabular}{|c|c|c|c|c|c|c|}
\hline $\begin{array}{l}\text { (I) Age group of } \\
\text { respondent }\end{array}$ & $\begin{array}{l}\text { (J) Age group of } \\
\text { respondent }\end{array}$ & MD (I-J) & Sig. & $\mathrm{F}$ & p-value & $\begin{array}{c}\text { Eta } \\
\text { square }\end{array}$ \\
\hline Less than 30 & $30-34$ years & $0.68 *$ & 0.01 & 6.816 & 0.00 & 0.119 \\
\hline \multirow[t]{6}{*}{ years } & 35 - 39 years & 0.41 & 0.38 & & & \\
\hline & $40-44$ years & 0.52 & 0.13 & & & \\
\hline & 45 - 49 years & 0.39 & 0.44 & & & \\
\hline & $50-54$ years & 0.16 & 0.99 & & & \\
\hline & 55 - 59 years & 0.17 & 0.99 & & & \\
\hline & 60 years and above & -0.06 & 1.00 & & & \\
\hline \multirow[t]{6}{*}{$30-34$ years } & 35 - 39 years & -0.27 & 0.15 & & & \\
\hline & $40-44$ years & -0.16 & 0.75 & & & \\
\hline & $45-49$ years & -0.28 & 0.11 & & & \\
\hline & $50-54$ years & $-0.52 *$ & 0.00 & & & \\
\hline & 55 - 59 years & $-0.51 *$ & 0.00 & & & \\
\hline & 60 years and above & $-0.74 *$ & 0.00 & & & \\
\hline \multirow[t]{5}{*}{35 - 39 years } & $40-44$ years & 0.10 & 0.98 & & & \\
\hline & 45 - 49 years & -0.01 & 1.00 & & & \\
\hline & 50 - 54 years & -0.25 & 0.31 & & & \\
\hline & 55 - 59 years & -0.24 & 0.49 & & & \\
\hline & 60 years and above & -0.47 & 0.09 & & & \\
\hline \multirow[t]{4}{*}{$40-44$ years } & 45 - 49 years & -0.12 & 0.96 & & & \\
\hline & 50 - 54 years & $-0.35^{*}$ & 0.04 & & & \\
\hline & 55 - 59 years & -0.35 & 0.11 & & & \\
\hline & 60 years and above & $-0.58 *$ & 0.02 & & & \\
\hline \multirow[t]{3}{*}{45 - 49 years } & 50 - 54 years & -0.23 & .414 & & & \\
\hline & 55 - 59 years & -0.23 & .596 & & & \\
\hline & 60 years and above & -0.46 & .125 & & & \\
\hline \multirow[t]{2}{*}{50 - 54 years } & 55 - 59 years & 0.00326 & 1.000 & & & \\
\hline & 60 years and above & -0.22531 & .891 & & & \\
\hline 55 - 59 years & 60 years and above & -0.22857 & .911 & & & \\
\hline
\end{tabular}

As Table 4 shows, there was a statistically significant difference at the $p<0.05$ in the academic staff levels 
Impact of socio-demographic factors on job satisfaction among academic staff of universities in Ghana

of job satisfaction for the eight groups $[\mathrm{F}(7,353)=6.816, p=0.00]$. The actual difference in mean scores between the groups was moderate. This interpretation was based on the recommendation of Cohen (1988) who avers that an eta square of 0.06 is moderate and eta square of 0.14 or more means that the margin of the difference between the groups is large. The effect size calculated using eta square was 0.119. Post-hoc comparisons using the Turkey HSD test indicated that the mean score for academic staff who were less than 30 years $($ Mean $=3.61$, Std. Dev. $=0.39)$ was significantly different from those who were within the age group of $30-34$ years $($ Mean $=2.92$, Std. Dev. $=0.63)$ with regard to their job satisfaction. The descriptive statistics of the variables further show that academics who were within the age group of $30-34$ years perceive their job satisfaction differently from those within the age groups of $50-54$ years, $55-59$ years and 60 years and above. The results in Table 4 show that academic staff who were on post-retirement contract (60 years and above) were more satisfied with their job than any of the age groups.

The finding of the current study that age significantly influenced job satisfaction of academic staff of public and private universities in Ghana confirms the findings reported by (Hunter, 2007; Lorber \& Skela-Savic, 2012) who in their studies found significant impact of age differences on job satisfaction of employees with older workers being more satisfied with their job than younger workers. The result of the current study gives the impression that older academics in public and private universities in Ghana have a deeper experience than younger academics with regard to their work. This finding corroborates Robins (2001) arguments that age significantly influences job satisfaction with older employees being more satisfied than the younger ones due to the experience they have gained. The outcome of the present study is also in line with the findings reported by (Nester \& Leady, 2000; Saba, 2011) who in their studies found significant age differences in job satisfaction of university academics with older academic staff reporting higher job satisfaction than younger academic staff. However, the finding of this study disconfirms the findings of Cano and Miller (1992) who in a study found no significant effect of age on job satisfaction of employees. This is also underscored by (Green, 2000; Andrews, 1990) who in their studies reported that age does not significantly influence job satisfaction of workers.

The possible reasons advanced in the literature for age differences in job satisfaction include the benefits that come with maintaining a long career, including higher salaries, fringe benefits and success in the work place. It must be pointed out that, although, the present study also found age as a significant predictor of job satisfaction among university academics in Ghana, it is possible that it may not be as a result of salary or fringe benefits. This is because both the young and the older academics in public and private universities in Ghana are not satisfied with the kind of salary and allowances as well as other paid-for activities such as research and supervision.

Also, one cannot rule out the differences in value orientation between the young and the old as a possible explanation for the significant age difference in job satisfaction among university academics in Ghana. It should be noted that younger workers have different values and motivation compared to older workers. The older university academics most probably would have different goals and motivation as compared to younger university academics and this may have accounted for the differences in their levels of job satisfaction. Another possible explanation for the age differences in job satisfaction among academic staff in Ghana could be attributed to the fact that most young university academics are still upwardly mobile and with age on their side they are most likely to explore other job opportunities or to seek for greener pastures in developed economies. Based on the findings, the study rejects the hypothesis that age does not have a statistically significant impact on job satisfaction among academic staff of public and private universities in Ghana.

To explore the impact of rank and category of university (public and private) on job satisfaction of academic staff of universities in Ghana, the two-way between group analysis of variance (ANOVA) was conducted. Respondents were divided into five groups according to their academic ranks (Group 1: Assistant lecturer; Group 2: Lecturer; Group 3: Senior lecturer; Group 4: Associate professor; Group 5: Professor). The ranks of the academic staff and category of university (public and private) were treated as the independent variables while the dependent variable was job satisfaction. Also, a post-hoc test was conducted using Tukey HSD to find where the 
Milledzi, E. Y., Amponsah, M. O., \& Asamani, L.

actual differences occur. In order to quantify the differences and also to know the margin of the differences, the eta square value was calculated for the differences if any. The descriptive statistics of the rank of academic staff, category of university and job satisfaction are shown in Table 5 .

Table 5

Descriptive Statistics of Academic Rank and University Category with regard to their Level of Job Satisfaction

\begin{tabular}{|c|c|c|c|c|}
\hline Academic rank of respondent & $\begin{array}{c}\text { Category of } \\
\text { university }\end{array}$ & Mean & Std. Dev. & $\mathrm{N}$ \\
\hline \multirow[t]{3}{*}{ Assistant lecturer } & Public & 3.39 & 0.50 & 68 \\
\hline & Private & 2.66 & 0.51 & 8 \\
\hline & Total & 3.32 & 0.55 & 76 \\
\hline \multirow[t]{3}{*}{ Lecturer } & Public & 2.87 & 0.51 & 137 \\
\hline & Private & 3.03 & 0.57 & 15 \\
\hline & Total & 2.88 & 0.52 & 152 \\
\hline \multirow[t]{3}{*}{ Senior lecturer } & Public & 3.60 & 0.54 & 86 \\
\hline & Private & 3.37 & 0.79 & 8 \\
\hline & Total & 3.58 & 0.56 & 94 \\
\hline \multirow[t]{3}{*}{ Associate professor } & Public & 3.32 & 0.59 & 25 \\
\hline & Private & 4.08 & 0.12 & 2 \\
\hline & Total & 3.37 & 0.61 & 27 \\
\hline \multirow[t]{3}{*}{ Professor } & Public & 3.37 & 0.35 & 8 \\
\hline & Private & 3.83 & 0.56 & 4 \\
\hline & Total & 3.53 & 0.46 & 12 \\
\hline \multirow[t]{3}{*}{ Total } & Public & 3.22 & 0.61 & 324 \\
\hline & Private & 3.17 & 0.70 & 37 \\
\hline & Total & 3.22 & 0.61 & 361 \\
\hline
\end{tabular}

Source. Field data, $2014(\mathrm{~N}=361)$. Dependent Variable: Job satisfaction.

As shown in Table 5, academic staff who were at the rank of assistant lecturer (Mean $=3.39$, Std. Dev. $=$ $0.50)$ and senior lecturer (Mean $=3.60$, Std. Dev. $=0.54$ ) of public universities were more satisfied than those in the private universities. However, academic staff who were at the rank of lecturer (Mean $=3.03$, Std. Dev. $=$ $0.57)$, associate professor $($ Mean $=4.08$, Std. Dev. $=0.12)$ and professor $($ Mean $=3.83$, Std. Dev. $=0.56)$ of private universities were more satisfied with their job than their counterparts with similar ranks in the public universities. The mean difference shows that academic staff of public universities (Mean $=3.22$, Std. Dev. $=0.61$ ) are slightly ahead of their private counterparts $($ Mean $=3.17$, Std. Dev. $=0.70)$ in terms of their levels of job satisfaction.

As Table 6 shows, there was a statistically significant difference at the $p<0.05$ in the academic staff levels of job satisfaction for the five groups $[\mathrm{F}(4,356)=26.68, p=0.00]$. The actual difference in mean scores between the groups was very large (Cohen, 1988). The magnitude of the difference between the various ranks among the academic staff with regard to their job satisfaction was 23.1 percent. The effect size calculated using eta square, was 0.231 .

Post-hoc comparisons using the Turkey HSD test indicated that the mean scores for lecturers (Mean $=2.89$, Std. Dev. $=0.52$ ) were significantly different from assistant lecturers $($ Mean $=3.32$, Std. Dev. $=0.55$ ), senior lecturers (Mean $=3.58$, Std. Dev. $=0.56$ ), associate professors $($ Mean $=3.38$, Std. Dev. $=0.61$ ) and professors $($ Mean $=3.53$, Std. Dev. $=0.47)$. Table 6 further shows that there is a significant difference between senior lecturers and assistant lecturers.

The findings in Table 6 also show that lecturers within the universities in Ghana were the least satisfied with their job than any other academic ranks in the universities. Senior lecturers were the most satisfied followed by professors, and associate professors. Some possible reasons could be assigned to senior lecturers as the most 
satisfied among the ranks. In the first place, it is possible that university academics that are young and are promoted as senior lecturers have the opportunity to rise to other higher ranks. In other words, young academic staff that have been promoted to the rank of senior lecturer have the potentials and capabilities to climb the academic ladder to top ranks such as associate professor and professor. Secondly, they have the opportunity to take part in certain key decisions and also to be appointed as departmental heads. On the other hand, the older university academics who are promoted as senior lecturers would naturally be satisfied with their job all things being equal because they would be given the opportunity to serve on post retirement contract.

\section{Table 6}

Rank Differences in Job Satisfaction among Academic Staff of Universities in Ghana

\begin{tabular}{|c|c|c|c|c|c|c|}
\hline $\begin{array}{l}\text { (I) Academic rank of } \\
\text { respondent }\end{array}$ & $\begin{array}{l}\text { (J) Academic rank of } \\
\text { respondent }\end{array}$ & $\begin{array}{l}\mathrm{MD} \\
(\mathrm{I}-\mathrm{J})\end{array}$ & Sig. & $\mathrm{F}$ & $\mathrm{p}$-value & $\begin{array}{c}\text { Eta } \\
\text { square }\end{array}$ \\
\hline Assistant lecturer & Lecturer & $0.43^{*}$ & 0.00 & 26.68 & 0.00 & 0.231 \\
\hline \multirow[t]{4}{*}{ Senior lecturer } & Assistant lecturer & $0.26^{*}$ & 0.02 & & & \\
\hline & Lecturer & $0.69^{*}$ & 0.00 & & & \\
\hline & Associate professor & 0.21 & 0.42 & & & \\
\hline & Professor & 0.05 & 0.99 & & & \\
\hline \multirow[t]{2}{*}{ Associate professor } & Assistant lecturer & 0.054 & 0.99 & & & \\
\hline & Lecturer & $0.49^{*}$ & 0.00 & & & \\
\hline \multirow[t]{3}{*}{ Professor } & Assistant lecturer & 0.21 & 0.74 & & & \\
\hline & Lecturer & $0.64^{*}$ & 0.00 & & & \\
\hline & Associate professor & 0.15 & 0.93 & & & \\
\hline
\end{tabular}

Based on the results, the study rejects the hypothesis that academic rank does not have a statistically significant impact on job satisfaction among academic staff of public and private universities in Ghana. The finding of this study confirms the findings of Oshagbemi (2003) who in a study found a significant effect of rank on job satisfaction of university academics. The foregoing also gives credence to what was reported by (Noble \& McCornic, 2008; Ssenga \& Garrett, 2005) who in their studies found significant effects of rank on levels of job satisfaction of workers. It is also in line with the perspectives of Holden and Black (1996) who reported significant effect of academic rank on the levels of job satisfaction and productivity among psychologists employed as faculty members in a medical school with employees at higher ranks having displayed higher levels of job satisfaction and productivity when compared with those at lower ranks.

The general trend indicates that higher rank employees report higher levels of job satisfaction because higher level jobs tend to be more complex and have better working conditions such as pay and promotion prospects. This corroborates Ssenger and Garrett (2005) argument that among Ugandan university academics rank is a significant predictor of job satisfaction therefore, significant differences exist in levels of job satisfaction between the various academic ranks. However, the foregoing is in sharp contrast to Platsidou and Diamatopoulou (2009) who indicated in their study that academic rank had no significant impact on job satisfaction which also underscores the results revealed in a study conducted in Northern Cyprus that no significant differences exist in job satisfaction between the various academic ranks because the level of job satisfaction among academics did not increase with rank (Eyupoglu \& Saner, 2009).

To investigate any significant impact of marital status on job satisfaction among academic staff of public and private universities in Ghana, the Two-way between groups Analysis of Variance (ANOVA) was employed. The marital status of the respondents were in four groups (Group 1: Single; Group 2: Married; Group 3: Divorced; Group 4: Widowed). The dependent variable considered was job satisfaction while the independent variables were marital status of respondents and university category (public and private). Also, a post-hoc test was conducted using Tukey HSD to find where the actual differences occur. In order to quantify the differences 
Milledzi, E. Y., Amponsah, M. O., \& Asamani, L.

and to know the margin of the differences, the eta square values were calculated. The descriptive statistics of the preliminary analysis is depicted in table 7.

\section{Table 7}

Descriptive Statistics of Marital Status and University Category with regard to their Level of Job Satisfaction

\begin{tabular}{|c|c|c|c|c|}
\hline Marital status of respondent & Category of university & Mean & $S D$ & $n$ \\
\hline \multirow[t]{3}{*}{ Single } & Public & 3.17 & 0.55 & 59 \\
\hline & Private & 2.75 & 1.09 & 4 \\
\hline & Total & 3.14 & 0.59 & 63 \\
\hline \multirow[t]{3}{*}{ Married } & Public & 3.23 & 0.61 & 261 \\
\hline & Private & 3.13 & 0.61 & 30 \\
\hline & Total & 3.22 & 0.61 & 291 \\
\hline \multirow[t]{3}{*}{ Divorced } & Public & 3.83 & 1.18 & 2 \\
\hline & Private & 4.08 & 0.12 & 2 \\
\hline & Total & 3.96 & 0.69 & 4 \\
\hline \multirow[t]{3}{*}{ Widowed } & Public & 3.50 & 0.47 & 2 \\
\hline & Private & 4.17 & 0.0 & 1 \\
\hline & Total & 3.72 & 0.51 & 3 \\
\hline \multirow[t]{3}{*}{ Total } & Public & 3.22 & 0.61 & 324 \\
\hline & Private & 3.17 & 0.71 & 37 \\
\hline & Total & 3.22 & 0.62 & 361 \\
\hline
\end{tabular}

Source. Field data, 2014. ( $=361)$. Dependent Variable: Job satisfaction.

Table 7 shows that academic staff who are single $($ Mean $=3.17$, Std. Dev. $=0.55)$ and married $($ Mean $=3.23$, Std. Dev. $=0.61$ ) with regard to their marital status in public universities are more satisfied than those in the private universities. However, in relation to academic staff who are divorced $($ Mean $=4.08$, Std. Dev. $=0.12)$ and widowed $($ Mean $=4.17$, Std. Dev. $=0.0$ ) of private universities, their levels of job satisfaction are higher than those who are divorced and widowed in public universities.

As Table 8 shows, there was a statistically significant difference at the $\mathrm{p}<0.05$ level in the marital status of academic staff of universities in Ghana with regard to their job satisfaction for the four groups $[\mathrm{F}(3,357)=2.95$, $p=0.03]$. The effect of the actual difference in mean scores between the groups was small. The effect size calculated using eta square, was 0.024 .

Table 8

Marital Status Differences among Academic Staff Regarding their Level of Job Satisfaction in the Universities

\begin{tabular}{|c|c|c|c|c|c|c|c|c|c|}
\hline $\begin{array}{l}\text { (I) Marital } \\
\text { status }\end{array}$ & $\mathrm{N}$ & Mean & $\begin{array}{l}\text { Std. } \\
\text { Dev. }\end{array}$ & $\begin{array}{l}\text { (J) Marital } \\
\text { status }\end{array}$ & $\begin{array}{l}\text { MD } \\
(\mathrm{I}-\mathrm{J})\end{array}$ & Sig. & $\mathrm{F}$ & $\mathrm{P}$-value & $\begin{array}{c}\text { Eta } \\
\text { square }\end{array}$ \\
\hline \multirow[t]{3}{*}{ Single } & 63 & 3.14 & 0.59 & Married & -0.08 & 0.81 & 2.95 & 0.03 & 0.024 \\
\hline & & & & Divorced & $-0.82^{*}$ & 0.05 & & & \\
\hline & & & & Widowed & -0.58 & 0.38 & & & \\
\hline \multirow[t]{2}{*}{ Married } & 291 & 3.22 & 0.61 & Divorced & -0.74 & 0.08 & & & \\
\hline & & & & Widowed & -0.50 & 0.49 & & & \\
\hline Divorced & 4 & 3.96 & 0.69 & Widowed & 0.24 & 0.96 & & & \\
\hline Widowed & 3 & 3.72 & 0.51 & & & & & & \\
\hline Total & 361 & 3.22 & 0.62 & & & & & & \\
\hline
\end{tabular}

Post-hoc comparisons using the Turkey HSD test indicated that the mean score for academic staff who are single $($ Mean $=3.14$, Std. Dev. $=0.59)$ is significantly different from those who are divorced $($ Mean $=3.96$, Std. Dev. $=0.69)$. The descriptive statistics of the categories further showed that university academics that are divorced are more satisfied with their jobs than any of the groups, followed by those that are widowed.

The study therefore rejects the hypothesis that marital status does not have a statistically significant impact 
on job satisfaction of public and private university academics in Ghana. The finding of the current study that marital status has a statistically significant impact on job satisfaction of academic staff of public and private universities in Ghana confirms the finding of Certin (2006) who in a study reported that marital status significantly effects job satisfaction of workers. The foregoing is also in line with the findings by (Olatunji, 2014; Rogers \& May, 2003) who in their studies concluded that marital status had a significant impact on levels of job satisfaction of workers. However, the finding of this study disconfirms the finding of Sonnert and Holton (1995) who in a study found no significant impact of marital status on job satisfaction.

The possible explanation for this finding on university academics who are divorced to be the most satisfied followed by those who are widowed in Ghana is that academic staff who are divorced or widowed do not have any marital commitment with their spouses. They can therefore stay at work for longer hours and come home at will considering the fact that in academia one needs a lot of time to conduct research and publish in order not to perish. It must be pointed out that in the Ghanaian socio- cultural setting, marriage comes with certain responsibilities. Therefore, combining work with marital responsibilities put some constraints on the individual and if not properly managed can affect job satisfaction levels. It is also possible that university academics that are divorced or widowed have older children who are well established and therefore they have enough time to concentrate on their profession as well as career development.

To examine the gender differences in job satisfaction, an independent sample t-test was conducted to compare male and female academic staff levels of job satisfaction. Prior to the data analysis, the assumptions of Independent samples t-test were assessed. The assumptions of Independent samples t-test are normality and homogeneity of variance. Homogeneity of variance was assessed with Levene's test and equal variances were assumed. The results are presented in Tables 9, 10 and 11.

In order to examine the difference in job satisfaction between male and female academic staff, the study first of all segregated the data between public and private universities and analyzed them separately before combining them together to examine the difference between all the respondents. Tables 9 and 10 present the results on private and public universities respectively.

\section{Table 9}

Gender Differences in Academic Staff Level of Job Satisfaction in Private University

\begin{tabular}{cllcccc}
\hline Variable & Gender & $\mathrm{N}$ & Mean & Std. Dev. & t-value & p-value \\
\hline Job satisfaction & Male & 25 & 3.13 & 0.78 & -0.77 & 0.45 \\
& Female & 12 & 3.32 & 0.54 & & \\
\hline
\end{tabular}

Source. Field data, 2014. ( $\mathrm{N}=37)$.

The results in Table 9 shows that there is no statistically significant gender difference in male academic staff $($ Mean $=3.13$, Std. Dev. $=0.78)$ and female academic staff $($ Mean $=3.32$, Std. Dev. $=0.54)$ levels of job satisfaction $[\mathrm{t}=-0.77, \mathrm{df}=35, p=0.45]$ of private universities in Ghana. With regard to public universities, as Table 10 shows, there is no statistically significant gender difference in male academic staff (Mean $=3.22$, Std. Dev. $=0.61)$ and female academic staff $($ Mean $=3.23$, Std. Dev. $=0.59)$ levels of job satisfaction $[\mathrm{t}=-0.15, \mathrm{df}=$ $322, p=0.87]$ of public universities in Ghana.

\section{Table 10}

Gender Differences in Academic Staff Level of Job Satisfaction in Public University

\begin{tabular}{ccccccc}
\hline Variable & Gender & $\mathrm{N}$ & Mean & Std. Dev. & t-value & p-value \\
\hline Job satisfaction & Male & 262 & 3.22 & 0.61 & -0.15 & 0.87 \\
& Female & 62 & 3.23 & 0.59 & & \\
\hline Source. Field data, 2014. $(\mathrm{N}=324)$. & & &
\end{tabular}

Since there were no gender differences among respondents in public and private universities, the study combined the data of both groups to further analyze to see whether there would be any differential. The results 
Milledzi, E. Y., Amponsah, M. O., \& Asamani, L.

are presented in Table 11.

\section{Table 11}

Gender Difference in University Academic Staff Levels of Job Satisfaction

\begin{tabular}{llccccc}
\hline \multicolumn{1}{c}{ Variable } & Gender & $\mathrm{N}$ & Mean & Std. Dev. & t-value & p-value \\
\hline Job & Male & 287 & 3.21 & 0.63 & -0.47 & 0.64 \\
satisfaction & Female & 74 & 3.25 & 0.58 & & \\
\hline
\end{tabular}

Source. Field data, 2014. $(\mathrm{N}=361)$. Where $\mathrm{N}=$ sample size and Std. Dev. = standard deviation.

The results in Table 11 indicate that there is no statistically significant gender difference in male academic staff $($ Mean $=3.21$, Std. Dev. $=0.63)$ and female academic staff $($ Mean $=3.25$, Std. Dev. $=0.58)$ levels of job satisfaction $[\mathrm{t}=-0.47, \mathrm{df}=359, p=0.64]$.

Based on the results in Table 11, the study fails to reject the hypothesis that there is no statistically significant difference in the job satisfaction levels of male and female academic staff of universities in Ghana. On the issue of no gender differences with regard to job satisfaction, the result of the current study provides credence for the studies by (Azim, Haque \& Chowdhurry, 2013) that established no significant gender differences in levels of job satisfaction and reported that both males and females were satisfied with their jobs. It is also consistent with the perspectives of Castillo et al., (2008) who noted that both males and females have reported no significant gender differences in their levels of job satisfaction. However, the result of this study is not consistent with the findings of (Ward \& Sloane, 2000; Clark, 1997; Long 2005) who in their studies found significant gender differences in levels of job satisfaction which also underscores the results revealed in a study by Olatunji (2014) that significant gender differences existed in job satisfaction among employees with males reporting high levels of job satisfaction than females.

The possible explanation that could be given to the current finding that established no significant gender difference in job satisfaction between male and female academic staff of universities in Ghana is that female academics most probably have same expectations as their male counterparts. Therefore, they have similar levels of job satisfaction. This is supported by (Barber, 1986; Jayaratne \& Chess, 1984; Rentner \& Bissland, 1990) who reported no significant differences between male and female employees with regard to promotion, financial rewards, work environment and role conflict. It must be noted that within the psychosocial environment in which this study was conducted, the public and private universities have equal level playing fields for both male and female academic staff with regard to appointment and promotion, work environment as well as salary and allowances.

Looking at the results, and considering the fact that academia in Ghana is male dominated, the dominance of males in the system could have accounted for differences in job satisfaction of university academics. This is because it is argued that in a male dominated culture, a woman is expected to accept whatever is given to her as a privilege and not as a right. It should be noted that although, other reasons beyond the scope of this study may have accounted for the results observed, it has been ascertained that gender does not significantly influence job satisfaction among university academics in Ghana. Therefore, whether one is a male or a female does not have an influence on such an individual's levels of job satisfaction.

\subsection{Implications for practice}

This study has shed light on job satisfaction among academic staff of universities in Ghana. Academic staff is a significant part of a modern research university. They are an important repertoire of professional skills, possess a wealth of institutional knowledge, provide essential resources, and work alongside Administration in realizing the University's mission. The implications are self-evident for university management and governing bodies. If academic staff are to be encouraged to experience higher job satisfaction then they should be supported to progress through the academic ladder without difficulties. Their work environment including decision making, promotion and reduction in role conflict and increase in financial rewards (Barber, 1986; 
Impact of socio-demographic factors on job satisfaction among academic staff of universities in Ghana

Jayaratne \& Chess, 1984; Rentner \& Bissland, 1990) should not be compromised.

Acknowledgments - First and foremost we offer our sincerest gratitude to the Institutional Review Board (IRB) of the University of Cape Coast, Ghana that reviewed the proposal and approved that the research be carried out. Additionally, we are most grateful to the Department of Education and Psychology Senior Members who attended the departmental seminar and provided useful contributions to this manuscript. We also acknowledge the immense suggestions given by colleagues at the U6 Consortium 4th International Conference held at the University of Cape Coast, Cape Coast, Ghana between 13th $-14^{\text {th- }}$ September, 2016. We are indebted to everyone who contributed directly or indirectly to this manuscript.

\section{References}

Andrews, G. L. (1990). An assessment of the interaction of selected personal characteristics and job satisfaction of extension agricultural agents. Journal of Agricultural Extension 25, 35-46.

Armstrong, M. (2006). A handbook of human resource management practice. New York: Kogan Page Publishers.

Azim, M. T., Haque, M. M., \& Chowdhury, R. A. (2013). Gender, marital status and job satisfaction among academic staff. Interdisciplinary Journal of Contemporary Research in Education, 1(2), 12-20.

Barber, G. (1986). Correlates of job satisfaction among human service workers. Administration in Social Work, 10(1), 25-38. https://doi.org/10.1300/J147v10n01_04

Bersoff, D., \& Crosby, F. (1984). Job satisfaction and family status. Personality and Social Psychology Bulletin, 10(1), 79-83. https://doi.org/10.1177/0146167284101008

Booth, A. L., Francesconi, M., \& Frank, J. (2002). Temporary jobs: Stepping stones or dead ends? Economic Journal, 12, 189-213. https://doi.org/10.1111/1468-0297.00043

Bowen, C. F., Radhakrishna, R. B., \& Keyser, R. (1994). Job satisfaction and commitment of employees. Journal of Agricultural Extension, 32(1), 54-67.

Brush, D. H., Moch, M. K., \& Pooyan, A. (1987). Individual differences in job satisfaction. Journal of Occupational Behaviour, 8, 139-156. https://doi.org/10.1002/job.4030080205

Burns, N., \& Grove, S. K. (2005). The practice of nursing research: Conduct, critique and utilization (5th ed.). St Louis: Elsevier Saunders.

Campbell, A., Converse, P. E., \& Rodgers, W. L. (1976). The quality of American life: Perceptions, evaluations, and satisfactions. New York: John Willey.

Cano, J., \& Miller, G. (1992). A gender analysis of job satisfaction factors among agricultural education teachers. Journal of Agricultural Education, 33(3), 40-46. https://doi.org/10.5032/jae.1992.02040

Castillo, J. X., Conklin, M., \& Cano, J. (2008). Factors explaining job satisfaction among faculty. Journal of Agricultural Education, 45(3), 65-74. https://doi.org/10.5032/jae.2004.03065

Cetin, M. O. (2006). The relationship between job satisfaction, occupational and organizational commitment of academics. Journal of American Academy of Business, 8(1), 78-89.

Clark, A. (1997). Job satisfaction and gender: Why are women so happy at work? Labour Economics, 4, $341-372$. https://doi.org/10.1016/S0927-5371(97)00010-9

Clark, A., Oswald, A., \& Warr, P. (1996). Is job satisfaction u-shaped in age? Journal of Occupational and Organizational Psychology, 69, 57-81. https://doi.org/10.1111/j.2044-8325.1996.tb00600.x

Cohen, L., Manion, L., \& Morrison, K. (2007). Research methods in education (6th ed.). London: Routledge.

Creswell, J. W. (2014). Research design: Qualitative, quantitative and mixed methods approaches $\left(4^{\text {th }} \mathrm{ed}.\right)$. Thousand Oaks, CA: Sage.

Daft, L. R., \& Noe, R. A. (2001). Organisational behaviour. Florida: Harcourt College Publishers.

Donohue, S. M., \& Heywood, J. S. (2004). Job satisfaction and gender: An expanded specification. International Journal of Manpower, 25(2), 211-238. https://doi.org/10.1108/01437720410536007

Eyupoglu, S. Z., \& Saner, T. (2009). Job satisfaction: Does rank make a difference? Journal of Business Management, 3(10) 609-615. 
Milledzi, E. Y., Amponsah, M. O., \& Asamani, L.

Field, A. P. (2005). Discovering statistics using SPSS (2nd ed.). London: Sage.

Forgionne, G. A., \& Peeters, V. E. (1982). Differences in job motivation and satisfaction among female and male managers. Human Relations, 35, 101-118. https://doi.org/10.1177/001872678203500202

Fowler, F. J. (2009). Survey research methods (2nd ed.). Thousand Oaks, CA: Sage. https://doi.org/10.4135/9781452230184

Fraenlkel, J. R., \& Wallen, N. E. (2006). How to design and evaluate research in education (6th ed.). New York: McGraw-Hill.

Grady, T. L. (1985). Job satisfaction of vocational agriculture teachers in Louisiana. Journal of American Association of Teacher Educators in Agriculture, 26(3), 70-78.

Green, M. A. (2000). Age and job satisfaction. Professional Psychology Research and Practice 28(14), 989-998.

Greenhaus, J. H., Parasuraman, S., \& Collins, K. M. (2001). Career involvement and family involvement as moderators of relationships between work-family conflict and withdrawal from a profession. Journal of Occupational Health Psychology, 6(2), 91-103. https://doi.org/10.1037/1076-8998.6.2.91

Hagedorn, L. S. (2000). Conceptualizing faculty job satisfaction: Components, theories and outcomes. San Francisco: Jossey-Bass.

Herzberg, F. (1959). The motivation to work (2nd ed.). New York: Wiley and Sons.

Holden, E. W., \& Black, M. M. (1996). Psychologists in medical schools: How are rank and tenure associated with productivity and satisfaction? Professional Psychology Research and Practice, 27(4), 407-414. https://doi.org/10.1037/0735-7028.27.4.407

Hulin, C., \& Smith, P. (1964). Sex differences in job satisfaction. Journal of Applied Psychology, 48(6) 88-92. https://doi.org/10.1037/h0040811

Hunter, E. P. (2007). Validity of the job characteristics model in team environment: Prediction of job satisfaction and potential moderators. Journal of Business Administration, 34, 142-153.

Jayaratne, S., \& Chess, W. A. (1984). Job satisfaction, burnout, and turnover: A national study. Journal of Social Work, 29(5), 448-453.

Kacmar, K. M., \& Ferris, G. R. (1989). Theoretical and methodological considerations in the age-job satisfaction relationship. Journal of Applied Psychology, 74, 201-207. https://doi.org/10.1037/0021-9010.74.2.201

Kessuwan, K., \& Muenjohn, N. (2010). Employee's satisfaction: work-related and personal factors. International Review of Business Research, 6(3), 168-177.

Kirk, R.E. (1995). Experimental design. London: Pacific Grove Brook.

Kuhlen, R. G. (1963). Needs, perceived need satisfaction opportunities. Journal of Applied Psychology, 47, 56-64. https://doi.org/10.1037/h0045338

Lacy, F. J., \& Sheehan, B. A. (1997). Job satisfaction among academic staff: An international perspective. Journal of Higher Education, 34(3), 305-322. https://doi.org/10.1023/A:1003019822147

Long, A. (2005). Happily ever after? A study of job satisfaction in Australia. The Economic Record, 81, 303-321. https://doi.org/10.1111/j.1475-4932.2005.00271.x

Lorber, M., \& Skela-Savic, B. (2012). Job satisfaction of nurses and identifying factors of job in hospitals. Croatian Medical Journal, 53(3), 263-270. https://doi.org/10.3325/cmj.2012.53.263

Martin, J. K., \& Hanson, S. L. (1985). Sex, family wage-earning status and satisfaction with work. Work and Occupations, 12(1), 91-109. https://doi.org/10.1177/0730888485012001006

McCarry, S. (2005). Motivating the workplace with a positive: Recognition that works. Franchising Worlds, 37(3), 54-57.

McNeely, R. L. (1984). Occupation, gender, and work satisfaction in a comprehensive human services department. Administration in Social Work, 8(2), 35-47. https://doi.org/10.1300/J147v08n02_04

Mullins, L. J. (2002). Management and organizational behaviour (4th ed.). New York: Prentice Hall.

Near, J. P., Rice, R. W., \& Hunt, R. G. (1978). Work and extra work correlates of life and job satisfaction. Academy of Management Journal, 21, 95-114. https://doi.org/10.2307/255758

Nel, P. S., Van-Dyk, P. S., Haasbroek, G. D., Scultz, H.B., Sano, T. J., \& Werner, A. (2004). Human resource management (6th ed.). Cape Town: Oxford University Press.

Nestor, P. I., \& Leady, P. (2000). The relationship between tenure and non-tenure track status of extension faculty 
Impact of socio-demographic factors on job satisfaction among academic staff of universities in Ghana

and job satisfaction. Journal of Agricultural Extension, 38(4), 8-13.

Nobile, J.J. \& McCormic, J. (2008). Organizational communication and job satisfaction in Australian catholic primary Schools. Educational Management, Administration and Leadership, 36(1) 101-122. https://doi.org/10.1177/1741143207084063

Olatunji, S. O. (2014). The influence of sex, marital status and tenure on job satisfaction of employees. Organisational Behaviour, 24(4), 389-416.

Oshagbemi, T. (1997). The influence of rank on job satisfaction of organizational members. Journal of Managerial Psychology, 12(8), 511-519. https://doi.org/10.1108/02683949710189111

Oshagbemi, T. (2003). Personal correlates of job satisfaction: Empirical evidence from universities in the United Kingdom. International Journal of Social Economics, 30(12), 210-231. https://doi.org/10.1108/03068290310500634

Pallant, J. (2001). SPSS survival manual: A step by step guide to data analysis using SPSS for windows. ST. Leonard, NSW: Allen \& Unwin.

Pearson, D. A., \& Seiler, R. E. (1983). Environmental satisfiers in academe: Job satisfaction as a function of job levels. Administration and Policy in Mental Health, 32(3), 285-291.

Platsidou, M., \& Diamantopoulou, G. (2009). Job satisfaction of Greek university professors: Is it affected by demographic factors, academic rank and problems of higher education? In G. K. Zarifis (Eds),

Educating the adult educator: Quality provision and assessment in Europe (pp. 535-545). Thessaloniki: Grafima Publications.

Polit, D. F., \& Beck, C. T. (2008). Nursing research: Generating and assessing evidence for nursing practice (8th ed.). Philadelphia: JB Lippincott.

Rentner, T. L., \& Bissland, J. H. (1990). Job satisfaction and its correlates among public relations workers. Journalism and Mass Communication Quarterly, 67(4), 950-955. https://doi.org/10.1177/107769909006700450

Rhodes, S. R. (1983). Age-related differences in work attitudes and behaviour: A review and conceptual analysis. Psychological Bulletin, 93, 328-367. https://doi.org/10.1037/0033-2909.93.2.328

Riggs, K., \& Beus, K. M. (1994). Job satisfaction among extension workers. Journal of Agricultural Extension, 32(2), 78-85.

Robbins, S. P. (2001). Organization behavior. New York: Prentice Hall Inc.

Rogers S. J., \& May, D. C. (2003). Spill over between marital quality and job satisfaction: Long-term patterns and gender differences. Journal of Applied Psychology, 4, 57-76.

Rogers S. J., \& May, D. C. (2003). Spill over between marital quality and job satisfaction: Long-term patterns and gender differences. Journal of Applied Psychology, 4, 57-76.

Saba, I. (2011). Measuring the job satisfaction level of the academic staff in Bahawalpur colleges. International Journal of Academic Research in Business and Social Science, 1, 221-235.

Saleh, S. D., \& Otis, J. L. (1964). Age and level of job satisfaction. Journal of Personnel Psychology, 17, 30-42. https://doi.org/10.1111/j.1744-6570.1964.tb00077.x

Sax, J. K., Fei, P., Murphy, M. E., Bernhard, E., Korsmeyer, S. J., \& El-Deiry, W. S. (2002). Faculty research productivity: Exploring the role of gender and family related factors. Research in Higher Education, 43(4), 423-446. https://doi.org/10.1023/A:1015575616285

Schneider, I. I. (2008). Motivation and organizational climate. Journal of Personnel Psychology, 29(3), 371-392.

Sesanga, K., \& Garrett, R. M. (2005). Job satisfaction of university academics: Perspectives from Uganda. Journal of Higher Education, 50(1), 33-56. https://doi.org/10.1007/s10734-004-6346-0

Shah, M. J. (2012). Job satisfaction and motivation of teachers of Public Education Institutions. International Journal of Business and Social Science, 3(8), 123-135.

Sloane, P., \& Williams, H. (2000). Job satisfaction, comparison earnings and gender. Journal of Labour Relations, 14, 473-501. https://doi.org/10.1111/1467-9914.00142

Sohail, M. T., \& Delin, H. (2013). Job satisfaction surrounded by academic society. American Sociologist, 16, 177-180.

Sonnert, G., \& Holton, G. J. (1995). Gender differences in science careers: The project access study. New 
Milledzi, E. Y., Amponsah, M. O., \& Asamani, L.

Brunswick, NJ: Rutgers University Press.

Sousa-Poza, A., \& Sousa-Poza, A. A. (2003). Gender differences in job satisfaction in Great Britain: Permanent or transitory? Applied Economic Letters, 10, 691-694. https://doi.org/10.1080/1350485032000133264

Spector, P. E. (1985). Measurement of human service staff satisfaction: Development of the job satisfaction survey. American Journal of Community Psychology, 13(6), 693-713. https://doi.org/10.1007/BF00929796

Tack, M. W., \& Patitu, C. L. (1992). Faculty job satisfaction: Women and minorities in peril. Journal of Higher Education, 4, 47-65.

Tuch, S. A., \& Martin, J. K. (1991). Race in the workplace. The Sociological Quarterly, 32(1), 103-116. https://doi.org/10.1111/j.1533-8525.1991.tb00347.x

Ward, M. E., \& Sloane, P. J. (2000). Job satisfaction among male and female academics in Scottish universities. Scottish Journal of Political Economy, 47(3), 273-303. https://doi.org/10.1111/1467-9485.00163

Warr, P. B. (1992). Age and occupational well-being. Psychology and Aging Journal, 7, 37-45. https://doi.org/10.1037/0882-7974.7.1.37

Warren, J. A., \& Johnson, P. J. (1995). The impact of workplace support on work family role strain. Family Relations, 44, 163-169. https://doi.org/10.2307/584803

Waskiewicz, S. P. (1999). Variables that contribute to job satisfaction of secondary school assistant principals. Unpublished doctoral dissertation, Virginia Polytechnic Institute and State University, USA.

Weaver, C. N. (1974). Correlates of job satisfaction: Some evidence from the national surveys. Academy of Management Journal, 17, 373-384. https://doi.org/10.2307/254992

Wolfinger, N. H., Mason, M. A., \& Goulden, M. (2008). Problems in the pipeline: Gender, marriage and fertility in the ivory tower. Journal of Higher Education, 79(4), 389-403. 